\title{
STUDIES OF THE VARIATIONS IN THE ANTISTREPTOLYSIN TITER OF THE BLOOD SERUM FROM PATIENTS WITH HEMORRHAGIC NEPHRITIS. II. OBSERVATIONS ON PATIENTS SUFFERING FROM STREPTOCOCCAL INFECTIONS, RHEUMATIC FEVER AND ACUTE AND CHRONIC HEMORRHAGIC NEPHRITIS
}

\author{
BY WARFIELD T. LONGCOPE 1 \\ (From the Medical Clinic, the School of Medicine, Johns Hopkins University and Hospital, \\ Baltimore)
}

(Received for publication January 15, 1936)

The observations recorded in the preceding section form a fairly satisfactory background for further investigations. In these studies, which may be regarded as controls, it was found that the titer of the antistreptolysin of the serum varied within narrow limits from one normal person to another, 75 per cent giving titers between 25 and 50 units. It was, in addition, noted that the antistreptolysin titer remained fairly constant in the same individual from month to month, provided a hemolytic streptococcal infection did not supervene. The antistreptolysin in the serum from patients affected by a variety of chronic diseases behaved in much the same manner as in normal persons, for only 14 out of 84 patients gave titers above 100 units, and none gave titers of 200 units or over. The serum from a limited number of acute infections, caused by agents other than hemolytic streptococci, were also examined, often at frequent intervals during the course of the disease. Though there was a tendency for the antistreptolysin content to remain within normal limits, both during the acute stage and during convalescence, 43 of 66 cases giving titers between 25 and 50 units, it was noted that the variations from person to person were a little more frequent than they were in the normal individual or in the chronically diseased. Titers slightly above those of the normal adult were occasionally encountered, 22.7 per cent of 66 cases giving titers above 100 units and 2 patients giving titers of 250 units. With this information in hand it was possible to consider the problem presented by patients with infections caused by hemolytic streptococci for we may conclude, as have others, that the antistreptolysin titer of the serum

1 The titrations of antihemolysin were made with the technical assistance of Cyril Skala. of the adult under normal conditions usually lies between 25 and 50 units and rarely exceeds 100 units. Persons with chronic disease or acute infections, not known to be associated with or complicated by hemolytic streptococcal infections, are more likely to show slightly higher titers than the normal.

We have selected several forms of hemolytic streptococcal infections for study. There are 19 cases of erysipelas, 18 cases of scarlatina, 14 cases of acute tonsillitis due to $B$. hemolytic streptococci, and 7 cases of miscellaneous infections due to hemolytic streptococci, from two of which minute hemolytic streptococci were recovered in pure culture by Dr. Long and Dr. Bliss. It was not possible, unfortunately, to follow any of these patients for long periods after recovery and since, as was originally pointed out by Todd (1) and has been emphasized by Coburn and Pauli (2), the antistreptolysin content of the serum may not rise until the patient has passed well into convalescence, our observations in many instances are incomplete. They serve, however, a certain purpose.

In Table I, the antistreptolysin titers of the serum from 19 instances of erysipelas are recorded. The sera were examined at times varying from the second day of the disease to the third month following recovery. It will be seen that in the first week of the disease, the sera from 6 out of 12 patients gave titers well above 100 units; in the second week 6 out of 8 gave titers above 100 units; and 5 of these gave titers of 200 units or more; in the third week 5 out of 5 gave titers above 100 units and four of these gave titers of 200 units or over. After the third week 3 out of 4 gave titers above 100 units and 1 of these gave a titer of 250 units. The table shows 
WARFIELD T. LONGCOPE

TABLE I

Antistreptolysin titers (units per cc.) of the blood serum of 19 cases of erysipelas

\begin{tabular}{|c|c|c|c|c|c|c|c|c|c|c|c|c|c|c|c|c|c|c|c|}
\hline \multirow{2}{*}{$\begin{array}{c}\text { Time } \\
\text { of } \\
\text { determi- } \\
\text { nation- }\end{array}$} & \multicolumn{19}{|c|}{ Patient number } \\
\hline & 1 & 2 & 3 & 4 & 5 & 6 & 7 & 8 & 9 & 10 & 11 & 12 & 13 & 14 & 15 & $16^{*}$ & 17 & 18 & 19 \\
\hline $\begin{array}{c}d a y \\
1 \\
2 \\
3 \\
4 \\
5 \\
6 \\
7 \\
8 \\
9 \\
10 \\
11 \\
12 \\
13 \\
14 \\
\text { week } \\
3 \\
4 \\
4 \\
\text { month } \\
2 \\
\\
\\
3\end{array}$ & $\begin{array}{l}50.0 \\
50.0\end{array}$ & 166.7 & $\begin{array}{l}250 \\
250\end{array}$ & 25 & 50.0 & $\begin{array}{l}250 \\
250 \\
250\end{array}$ & 250 & \begin{tabular}{|c}
50.0 \\
\\
\\
125
\end{tabular} & 250 & 250 & 125 & $\begin{array}{l}50.0 \\
50.0 \\
50.0 \\
50.0 \\
50.0 \\
50.0\end{array}$ & $\begin{array}{r}333.3 \\
333.3 \\
\end{array}$ & $\begin{array}{c}33.3 \\
50.0\end{array}$ & $\begin{array}{l}125 \\
125\end{array}$ & $\begin{array}{l}125^{*} \\
125\end{array}$ & 25 & $\begin{array}{l}125 \\
125 \\
125\end{array}$ & \begin{tabular}{|l}
166.7 \\
166.7 \\
166.7
\end{tabular} \\
\hline
\end{tabular}

* One month after infection of throat due to B. hemolytic streptococcus, and 1 week after acute pharyngitis due to $B$. hemolytic streptococcus.

TABLE II

Antistreptolysin titers (units per cc.) of the blood serum from 18 cases of scarlatina

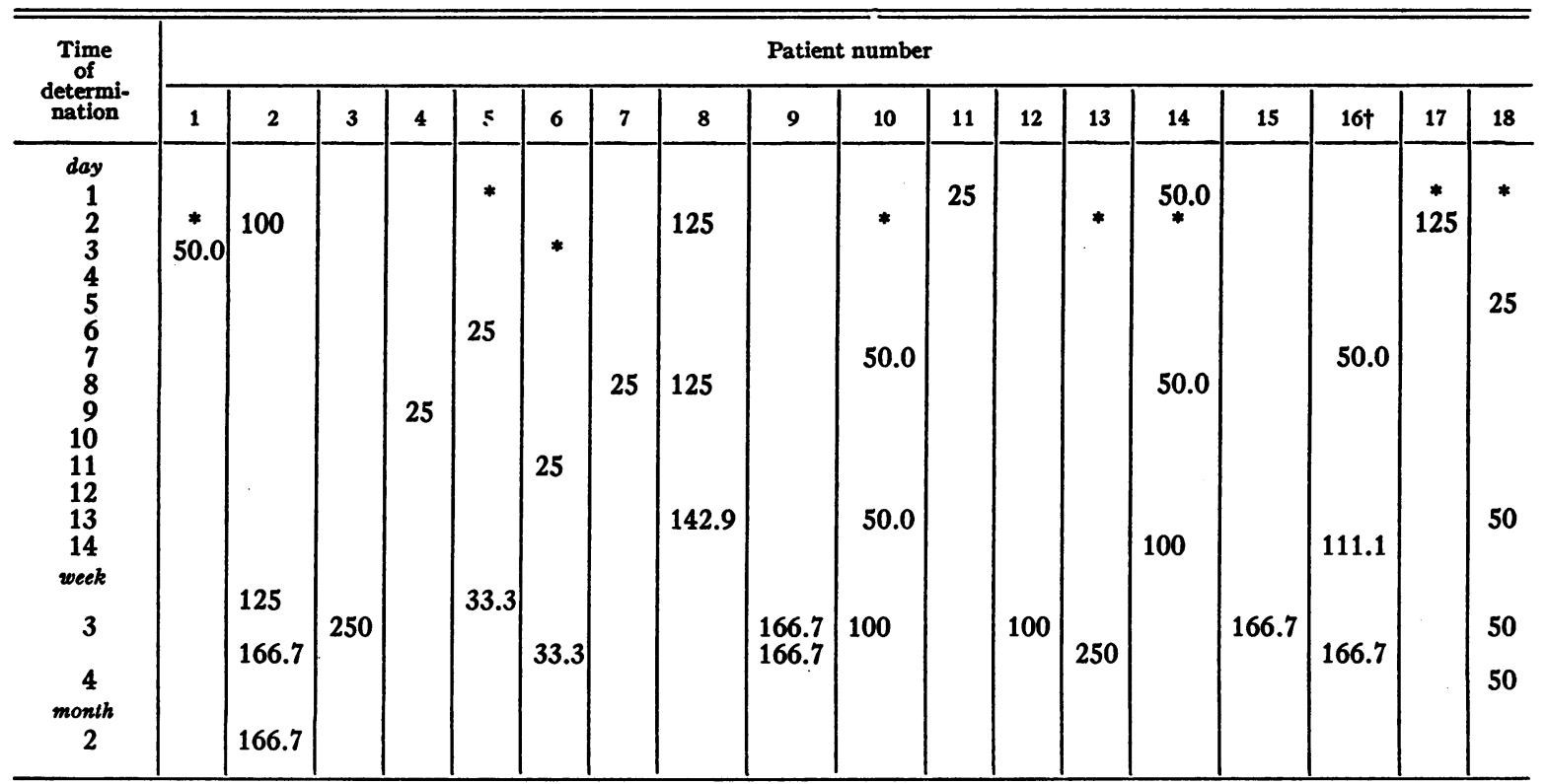

* Scarlatinal antitoxin.

$\dagger$ Puerperal infection and scarlatina. 
that during the first few weeks of the disease there was usually a rapid increase in the antistreptolysin content of the serum, but the numbers of observations are too small to enable one to demonstrate that this actually occurred in each individual. In Case 8 the antistreptolysin titer rose from 50 units in the first week to 125 units in the third week. In Cases 6,13,18 and 19 the titers remained unchanged throughout the course of the disease, and in Case 13 remained constantly at an elevated titer of 333 units for 3 weeks.

In scarlet fever, though our observations are meager, they nevertheless show that there is the same tendency towards an increase in antistreptolysin titer of the serum in the third week of the disease (Table II). The titers are not very high, and an increase above 100 units was only noticed in 8 of the 18 cases, and above 200 units in 2 cases.

TABLE III

Antistreptolysin titers (units per cc.) of the blood serum from 14 cases of acute tonsillitis

\begin{tabular}{|c|c|c|c|c|c|c|c|c|c|c|c|c|c|c|}
\hline \multirow{2}{*}{$\begin{array}{l}\text { Time } \\
\text { of de- } \\
\text { termi- } \\
\text { nation }\end{array}$} & \multicolumn{14}{|c|}{ Patient number } \\
\hline & 1 & 2 & 3 & 4 & 5 & 6 & 7 & 8 & 9 & 10 & 11 & 12 & 13 & 14 \\
\hline $\begin{array}{c}\text { day } \\
1 \\
2 \\
3 \\
4 \\
5 \\
6 \\
7 \\
8 \\
9 \\
10 \\
11 \\
12 \\
13 \\
14 \\
\text { week } \\
3 \\
4 \\
\text { month } \\
2 \\
3\end{array}$ & 50.0 & $\begin{array}{l}25 \\
100\end{array}$ & 25 & 125 & 100 & 125 & \begin{tabular}{|c|}
25 \\
50.0
\end{tabular} & 50.0 & 50.0 & $25 \mid$ & 250 & $\begin{array}{l}125 \\
200 \\
200 \\
\\
250 \\
333 \\
200\end{array}$ & $\begin{array}{l}50.0 \\
50.0\end{array}$ & $\begin{array}{l}166.7 \\
333.3\end{array}$ \\
\hline
\end{tabular}

In tonsillitis these elevations were even less common than they were in erysipelas and scarlatina (Table III). There is, however, again a tendency for the titer to rise during the latter part of the disease or in convalescence. Five of the fourteen cases gave titers above 100 units in the second or third week and three of these gave titers of 200 or above. Case 12 demonstrates very well the rise of the antistreptolysin titer in the third week of the disease and the persistence of high titers (after recovery) for three months.

In the group of miscellaneous infections due to hemolytic streptococci there are only 7 cases (Table IV). Three of these showed an increased

TABLE IV

Antistreptolysin titers (units per cc.) of the blood sera from 7 cases of miscellaneous infections due to hemolytic streptococci

\begin{tabular}{|c|c|c|c|c|c|c|c|}
\hline \multirow{2}{*}{$\begin{array}{c}\text { Time of } \\
\text { determination }\end{array}$} & \multicolumn{7}{|c|}{ Patient number } \\
\hline & 1 & 2 & 3 & 4 & 5 & 6 & 7 \\
\hline $\begin{array}{c}\text { day } \\
1 \\
2 \\
3 \\
4 \\
5 \\
6 \\
7 \\
\text { week } \\
2 \\
3 \\
4 \\
\text { month } \\
1 \text { to } 2 \\
\\
2 \text { to } 3 \\
3 \text { to } 4\end{array}$ & 250 & 25 & 25 & $\begin{array}{c}333.3 \\
500 \\
1250 \\
1429 \\
500 \\
\\
555\end{array}$ & 50 & $\begin{array}{l}50 \\
\\
50 \\
33.3 \\
33.3 \\
25\end{array}$ & $\begin{array}{l}125 \\
125\end{array}$ \\
\hline
\end{tabular}

antistreptolysin titer above 100 units. The number of cases is so small that they are important only on the following account. Case 4 was a boy, age 13, who developed a severe infection perforating the skull and involving the brain. From this pus and from secondary abscesses Drs. Long and Bliss cultivated minute hemolytic streptococci in pure culture. Minute hemolytic streptococci were also cultivated from the antrum in Case 6. In view of the fact that at the present time there is no information as to whether minute hemolytic streptococci are capable of inciting antistreptolysins for the oxygen labile streptolysin formed during the growth of hemolytic streptococci Group A of Lancefield, these observations are significant. Todd ( 3 ) has recently published a comparative study of the streptolysins and antistreptolysins produced by strains belonging to the different Lancefield groups (3a). It was found that the antistreptolysin produced by a strain from Lancefield Group A (human) did not neutralize hemolysin elaborated by strains from 
Group B (bovine), Group C (animal), Group D (cheese), or Group E (milk). Todd states that hemolytic streptococci belonging to Lancefield's Groups B, C, D and E are oxygen stabile and are non-antigenic. It is therefore important to know that the serum from a patient bearing a severe infection due to minute hemolytic streptococci which are placed by Lancefield (4) in Group F, may possess a very high antistreptolysin content. In fact, the serum from this patient (Number 4) gave the highest antistreptolysin titers that we have so far encountered. The serum from the second patient (Case 6) infected with minute hemolytic streptococci showed no increase in antistreptolysin above the normal on the single occasion upon which an examination was made. and least frequently in acute tonsillitis and miscellaneous streptococcal infections.

The observations of Coburn and Pauli (2) are among the most extensive in this connection. Single observations made 4 weeks after recovery from acute hemolytic streptococcal infections in a group of 26 non-rheumatic cases showed that 10 per cent following scarlatina; 16 per cent following mastoiditis; and 50 per cent following pharyngitis had titers below 200 units. Repeated observations were made in 24 cases of streptococcal pharyngitis. The antistreptolysin curves varied a great deal in the different cases, not only in respect to the height of the titer but as to the time after infection at which the highest titer was attained. In 55 per cent the maximum

TABLE V

Antistreptolysin titer from 58 cases of acute infections due to hemolytic streptococci

\begin{tabular}{|c|c|c|c|c|c|c|c|c|c|c|c|c|c|c|c|}
\hline \multirow{2}{*}{ Diagnosis } & \multicolumn{11}{|c|}{ Antistreptolysin titers (units per $c c$. ) } & \multicolumn{2}{|c|}{$\begin{array}{l}\text { Titers above } \\
100 \text { units }\end{array}$} & \multicolumn{2}{|c|}{$\begin{array}{c}\text { Titers } \\
200 \text { units + }\end{array}$} \\
\hline & 25 & 33.3 & 50 & 100 & 125 & $\mid 142.9$ & 166.7 & 250 & 333.3 & 1429 & $\left|\begin{array}{c}\text { Total } \\
\text { number } \\
\text { of cases }\end{array}\right|$ & $\underset{\text { ber }}{\text { Num- }}$ & \begin{tabular}{|c|} 
Per \\
cent
\end{tabular} & $\underset{\text { ber }}{\text { Num- }}$ & \begin{tabular}{|c} 
Per \\
cent
\end{tabular} \\
\hline $\begin{array}{r}\text { Erysipelas. . . . } \\
\text { Scarlatina . . . } \\
\text { Tonsillitis.... } \\
\text { Miscellaneous. } \\
\text { Total. . . }\end{array}$ & $\begin{array}{l}2 \\
3 \\
2 \\
2 \\
9\end{array}$ & 2 & $\begin{array}{r}4 \\
2 \\
5 \\
2 \\
13\end{array}$ & $\begin{array}{l}3 \\
2 \\
5\end{array}$ & $\begin{array}{l}5 \\
1 \\
2 \\
1 \\
9\end{array}$ & 1 & $\begin{array}{l}2 \\
4\end{array}$ & $\begin{array}{l}5 \\
2 \\
1 \\
1 \\
9\end{array}$ & $\begin{array}{l}1 \\
2 \\
3\end{array}$ & $\begin{array}{l}1 \\
1\end{array}$ & $\begin{array}{r}19 \\
18 \\
14 \\
7 \\
58\end{array}$ & $\begin{array}{r}13 \\
8 \\
5 \\
3 \\
29\end{array}$ & \begin{tabular}{|l|}
68.4 \\
44.4 \\
35.7 \\
42.8 \\
50
\end{tabular} & $\begin{array}{r}6 \\
2 \\
3 \\
1 \\
12\end{array}$ & $\begin{array}{l}31.5 \\
11.1 \\
21.4 \\
14.2 \\
20.7\end{array}$ \\
\hline
\end{tabular}

These observations upon infections known to be associated with hemolytic streptococci, which are summarized in Table $\mathrm{V}$, furnish results that are comparable to those previously published. During the first week of the acute infection the antistreptolysin was not often increased. By the third week of disease or of convalescence the titer increased and in one-half of our cases was found at this time to be above the upper normal limit of 100 units. In 13 or 22.4 per cent the titer was 200 units or above. Exact information as to the variations in the antistreptolysin content of the serum in these infections, as to the period in the infection at which the rise first occurs, and as to the duration of an elevated titer after the infection subsides is difficult to obtain, and much more study is required before one can completely comprehend this problem. It appears, however, from these figures that antistreptolysin is most regularly increased in erysipelas, next in scarlatina, level was under 200 units. Nearly all the patients developed a secondary rise some months after the primary maximum. Moderately elevated titers sometimes continued for four to five months. From these determinations, as well as those obtained in healthy persons and in a variety of chronic and acute diseases not caused by hemolytic streptococci, they conclude that an antistreptolysin titer of 200 units or above in any one person is a fairly clear indication of a recent infection by hemolytic streptococci in that individual.

Before analyzing the results obtained from a determination of the antistreptolysin content of the serum in acute nephritis, it is necessary to consider another group of patients in which the disease is by many thought to be associated with infections by hemolytic streptococci. We have selected for this purpose, 1-rheumatoid arthritis; 2-erythema multiforme and erythema nodosa, both of which affections may occur during 
TABLE VI

Antistreptolysin titers of sera from cases of rheumatoid arthritis and from patients with erythema multiforme, chorea, and active rheumatic heart disease and arthritis

\begin{tabular}{|c|c|c|c|c|c|c|c|c|c|c|c|c|c|c|c|c|c|c|c|}
\hline Diagnosis & 12.5 & 16.7 & 25 & 50.0 & 100 & 111.1 & 125 & 142.9 & 166.7 & 200 & 250 & 333.3 & 500 & 1000 & $\begin{array}{l}\text { Total } \\
\text { num- } \\
\text { ber of } \\
\text { cases }\end{array}$ & $\underset{\text { ber }}{\text { Num- }}$ & $\begin{array}{c}\text { Per } \\
\text { cent }\end{array}$ & $\underset{\text { ber }}{\text { Num- }}$ & $\begin{array}{c}\text { Per } \\
\text { cent }\end{array}$ \\
\hline Rheumatoid arthritis..... & 1 & 3 & 9 & 11 & 6 & & 8 & & 8 & & 9 & & & & 55 & 25 & 45.5 & 9 & 18.2 \\
\hline $\begin{array}{l}\text { Erythema multiforme and } \\
\text { nodosum } \ldots \ldots \ldots \ldots \ldots \ldots \\
\text { Chorea } \ldots \ldots \ldots \ldots \ldots \\
\text { Rheumatic fever, acute } \ldots \ldots\end{array}$ & & & 1 & $\begin{array}{l}1 \\
1 \\
3\end{array}$ & 3 & 1 & $\begin{array}{l}1 \\
8\end{array}$ & 2 & $\begin{array}{l}1 \\
2 \\
5\end{array}$ & $\begin{array}{l}1 \\
3\end{array}$ & $\begin{array}{l}1 \\
2 \\
9\end{array}$ & $\begin{array}{l}1 \\
6\end{array}$ & $\begin{array}{l}2 \\
4\end{array}$ & 2 & $\begin{array}{r}5 \\
8 \\
47\end{array}$ & $\begin{array}{r}4 \\
7 \\
40\end{array}$ & \begin{tabular}{l|}
80 \\
87.5 \\
85.1
\end{tabular} & $\begin{array}{r}3 \\
4 \\
24\end{array}$ & $\begin{array}{l}60 \\
50 \\
51\end{array}$ \\
\hline $\begin{array}{l}\text { Total rheumatic fever and } \\
\text { allied conditions........ }\end{array}$ & & & 1 & 5 & 3 & 1 & 9 & 2 & 8 & 4 & 12 & 7 & 6 & 2 & 60 & 51 & 85 & 31 & 51.6 \\
\hline
\end{tabular}

the course of acute rheumatic fever; 3 -chorea; and finally 4 -active rheumatic fever.

It may be seen from Table VI that the antistreptolysin content of the serum was regularly elevated in all these conditions, except rheumatoid arthritis. In rheumatoid arthritis this was true of the serum from less than one-half of the 55 patients studied; in the active rheumatic affections it was true of the sera from the majority of the 60 cases ( 85 per cent). The table shows almost precisely the reverse of the conditions as they existed in the chronic diseases and in the acute infections that were not caused by hemolytic streptococci. As a matter of fact the increase in the antistreptolysin content of the serum was much more striking in active rheumatic fever than it was in such acute infections caused by hemolytic streptococci as scarlatina, erysipelas and tonsillitis; for in 31 , or over 50 per cent, of the acute rheumatics the titers were 200 or above.

Table VII gives comparative figures for the highest titers obtained during the acute phase of a rheumatic infection (in the majority of cases rheumatic heart disease) and in chronic inactive heart disease (18 cases). Even though the number of cases of chronic inactive rheumatic heart disease is small, the difference, which has previously been pointed out by Coburn and Pauli in a much larger series, is striking.

Figure 1 shows the changes taking place from week to week and from month to month in the antistreptolysin titer of the serum from 47 cases of active rheumatic infection. The changes correspond very well to those that have been previously described (2), and show that during the first few months of an exacerbation, for in only five was the attack thought to be primary, the titer was almost invariably high. With improvement or recovery from the attack the titer tended to fall, at times rapidly, but at other times quite slowly, for in two cases the titer remained above 200 units for 6 months and in 6 cases above 100 units for almost a year. In three cases the titer did not rise above 100 during the course of the observations. The highest titers were observed in the most serious cases with prolonged clinical course.

These observations add nothing to what has al-

TABLE VII

Highest antistreptolysin titers from 47 cases of rheumatic fever and 18 cases of inactive rheumatic heart disease

\begin{tabular}{|c|c|c|c|c|c|c|c|c|c|c|c|c|c|c|c|c|c|}
\hline & 25 & 50 & 100 & $\mid 111.1$ & 125 & 142.9 & 166.7 & 200 & 250 & 333.3 & \begin{tabular}{|l|l|}
3 & 500 \\
\end{tabular} & 1000 & $\begin{array}{l}\text { Total } \\
\text { num- } \\
\text { ber of } \\
\text { cases }\end{array}$ & $\underset{\text { ber }}{\text { Num- }}$ & $\begin{array}{c}\text { Per } \\
\text { cent }\end{array}$ & $\stackrel{\text { Num- }}{\text { ber }}^{\text {Num }}$ & $\begin{array}{l}\text { Per } \\
\text { cent }\end{array}$ \\
\hline $\begin{array}{l}\text { Acute rheumatic fever........... } \\
\text { Chronic inactive rheumatic heart } \\
\text { disease } \ldots \ldots \ldots \ldots \ldots \ldots \ldots \ldots\end{array}$ & $\begin{array}{l}1 \\
6\end{array}$ & $\begin{array}{l}3 \\
5\end{array}$ & $\begin{array}{l}3 \\
2\end{array}$ & 1 & $\begin{array}{l}8 \\
3\end{array}$ & 2 & $\begin{array}{l}5 \\
2\end{array}$ & 3 & 9 & 6 & 4 & 2 & $\begin{array}{l}47 \\
18\end{array}$ & $\begin{array}{r}40 \\
5\end{array}$ & $\begin{array}{l}85.1 \\
27.7\end{array}$ & $\begin{array}{r}24 \\
0\end{array}$ & 51 \\
\hline
\end{tabular}




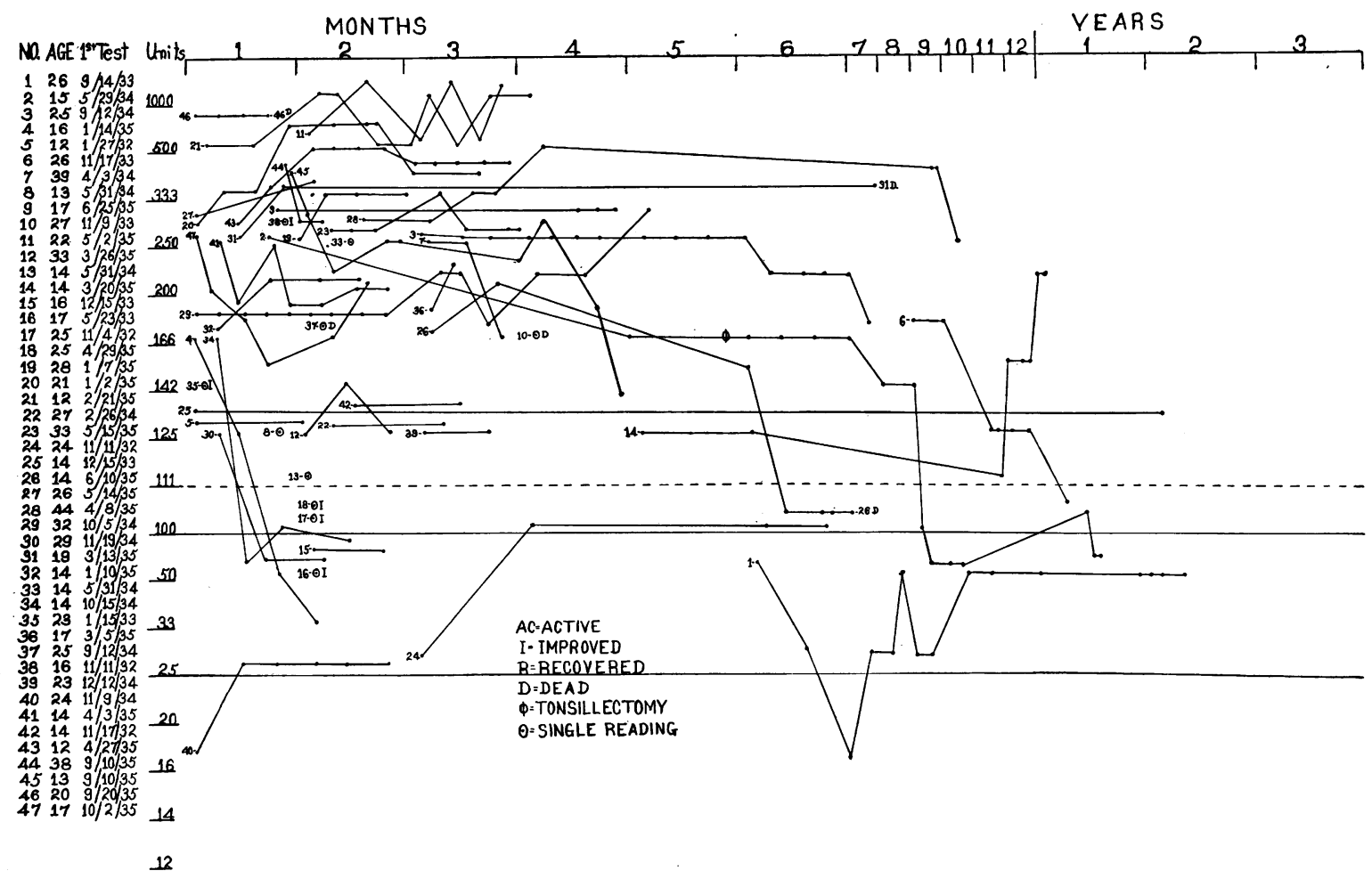

Fig. 1. Curves of Antistreptolysin Titer of the Blood Serum from 47 Cases of Acute Rheumatic Fever.

ready been published on this subject, but they are of value since they furnish data derived from patients with rheumatic fever in Baltimore and may therefore be used for comparative purposes in a study of the antistreptolysin content of the serum from cases of hemorrhagic nephritis, occurring in the same region. ${ }^{2}$

2 It has become obvious that these control studies of the antistreptolysin content of the serum from normal individuals, from patients suffering from chronic diseases and from infections other than those due to hemolytic streptococci, as well as from infections due to hemolytic streptococcus and from rheumatic fever are important, for Coburn and Pauli (10) have recently shown that the antistreptolysin content of the serum in healthy individuals may vary to a certain extent according to the latitude in which these individuals live. They have collected statistics to show that below latitude $35^{\circ}$ the median value for healthy individuals was 71 units and that serum from 78 per cent of the individuals showed a titer below 100 units. Above latitude $35^{\circ}$ the median titer of antistreptolysin of serum from 231 individuals was 100 units and the serum from only 58 per cent of the individuals showed an antistreptolysin titer of less than 100 units. It will be observed that throughout our observations the antistreptolysin titers are generally somewhat lower than those reported from Boston and New York both for healthy individuals and for individuals affected by hemolytic streptococci.
As our experience with acute nephritis has increased we have, from time to time, over the period in which we have been studying it, altered our views with regard to many phases of the disease and modified somewhat our conception of the process. It now seems probable that the disease which is designated as diffuse glomerular nephritis may assume two more or less distinct forms. These two forms have been very well differentiated by Winkenwerder, McLeod and Baker in a survey of our cases (5).

The first is the more common. This form follows in its general symptomatology and course the descriptions usually given of the disease. The onset follows within 5 to 21 days a more or less severe infection of the tonsils, respiratory tract or more rarely of the skin. It is the form that complicates scarlet fever. The infection preceding it is in the vast majority of cases due to hemolytic streptococci. The onset of symptoms is usually abrupt. In the severe cases there is fever, nausea, vomiting, pain in the lumbar region, suppression of urine or anuria. A peculiar form of anasarca develops rapidly. It produces a firm gelatinous swelling of the tissue, with very little 
pitting. There is a precipitous rise in blood pressure, occasionally acute dilatation of the heart and sometimes dyspnea. Costovertebral tenderness is frequent. There is albuminuria, sometimes of only moderate degree, but the urine contains numerous red blood cells, casts of many varieties and frequently many leukocytes. Rarely hemorrhages and exudates are seen in the retina. In the severest cases, there is reduction of phthalein excretion, elevation of nonprotein nitrogen of the blood and a low urea or xylose clearance.

Milder forms are quite common. In these there may be no fever, only slight facial edema, only transient hypertension, and no alteration in the renal function except for the inability to concentrate the urine normally. The hematuria, albuminuria and cylindruria are distinctive.

The particular features that distinguish this variety from the second form are the preceding acute infection always accompanied by a more or less severe constitutional reaction, the sudden onset, the time of which is often unmistakable, and the rapidity with which many cases improve. In rare instances the patient dies either from the original infection, an associated infection such as pneumonia, or in acute uremia. Much more often the improvement from the acute stage even in severe cases is comparatively rapid. The patient may later pass through various phases of the disease and experience exacerbations with recurring streptococcal infections, or in unfavorable cases pass into a nephrotic stage much like that observed in the second form. Eventually, however, recovery or complete quiescence takes place in a fair majority of patients ( 85 per cent of 61 cases of this type). Once complete recovery has been established, recurrences and exacerbations have not been observed, even though the patient might suffer at one time or another from an acute infection due to hemolytic streptococci.

The second form (designated Type B) is distinctly less common. Two distinguishing features are; first, that the disease is not usually preceded by any infection of which the patient is aware, and secondly, that the onset is so insidious that the exact time of its appearance can not often be accurately ascertained. In the majority of instances the patient first notices swelling of the feet, which gradually involves the entire body.
In other instances albumin is found accidentally in the urine, and edema appears later. Usually, there are no other initial symptoms. The blood pressure is normal or only moderately elevated, the retinae show edema, but no exudates or hemorrhages. Albuminuria is marked, there is hematuria of varying degree and cylindruria. The renal function, otherwise, is rarely affected. Careful examination usually reveals some chronic or indolent infection. This usually affects the accessory facial sinuses, the tonsils or the lower respiratory tract. The infection is often, but not always associated with hemolytic streptococci, sometimes of the alpha type. At times only the minute form of hemolytic streptococci, described by Long and Bliss (5a), has been obtained in culture. The course is often punctuated by acute exacerbations with increased blood pressure, gross hematuria and increase in albuminuria. Though the persistent dropsy is one of the characteristics of this type of the disease, edema may almost disappear, spontaneously, following such an acute exacerbation. Edema usually persists for months and may be present off and on for years. The patient may die in the subacute nephrotic stage a few months or a year or two after the onset, or may progress to a quiescent stage, with little or no edema, and only moderate hypertension, but with marked albuminuria and constant microscopic hematuria that varies in degree from time to time. Under these circumstances, the disease often terminates with hypertension, and the patient dies in uremia with some edema. In 25 cases of this type there were no complete recoveries, for the disease was fatal or resulted in a slowly progressive chronic and incurable nephritis in all.

It has seemed desirable, therefore, to consider the antibody response to streptolysin as it was observed in three separate groups of cases of nephritis. Types A and B include all the instances of hemorrhagic nephritis of which there were 97. Type $C$ does not include any instances of hemorrhagic nephritis.

There were 78 cases of acute active hemorrhagic nephritis belonging to the form first described (Type A). Thirty-six of these patients have recovered, 17 of them having been followed 
TABLE VIII

Highest antistreptolysin titers of serum from 57 cases of hemorrhagic nephritis (Type A), 19 cases of hemorrhagic nephritis (Type B) and 18 cases in the miscellaneous group (Type C)

\begin{tabular}{|c|c|c|c|c|c|c|c|c|c|c|c|c|c|c|c|c|c|c|c|c|c|c|}
\hline \multirow[b]{2}{*}{ Diagnosis } & \multicolumn{17}{|c|}{ Antistreptolysin titers (units per cc.) } & \multirow{2}{*}{$\mid \begin{array}{l}\text { Total } \\
\text { num- } \\
\text { ber of } \\
\text { cases }\end{array}$} & \multicolumn{2}{|c|}{$\begin{array}{c}\text { Titers above } \\
100 \text { units }\end{array}$} & \multicolumn{2}{|c|}{$\begin{array}{l}\text { Titers above } \\
200 \text { units }\end{array}$} \\
\hline & 10 & 12.5 & 14.2 & 16.7 & 20 & 25 & 33.3 & 50 & 100 & 111.1 & 125 & 142.9 & 166.7 & 200 & 250 & 333.3 & 500 & & $\begin{array}{c}\text { Num- } \\
\text { ber }\end{array} \mid$ & \begin{tabular}{|c|}
$\begin{array}{c}\text { Per } \\
\text { cent }\end{array}$ \\
\end{tabular} & $\underset{\text { ber }}{\text { Num- }}$ & $\begin{array}{l}\text { Per } \\
\text { cent }\end{array}$ \\
\hline \multicolumn{23}{|c|}{ Acute hemorrhagic nephritis (Type A) } \\
\hline $\begin{array}{l}\text { Acute stage........ } \\
\text { Quiescent and } \\
\text { chronic......... } \\
\text { After recovery } \\
\text { from nephritis... }\end{array}$ & & & & $\begin{array}{l}1 \\
1 \\
3\end{array}$ & & $\begin{array}{r}3 \\
5 \\
14\end{array}$ & $\begin{array}{l}1 \\
2 \\
2\end{array}$ & $\begin{array}{l}4 \\
9 \\
8\end{array}$ & $\begin{array}{l}1 \\
5 \\
3\end{array}$ & & $\begin{array}{l}3 \\
4 \\
1\end{array}$ & 1 & $\begin{array}{l}7 \\
4 \\
1\end{array}$ & 3 & $\begin{array}{l}7 \\
1\end{array}$ & 3 & 1 & $\begin{array}{l}36 \\
31 \\
36\end{array}$ & $\begin{array}{r}26 \\
9 \\
6\end{array}$ & $\left|\begin{array}{l}72.2 \\
29 \\
16.6\end{array}\right|$ & $\begin{array}{r}15 \\
1 \\
3\end{array}$ & $\begin{array}{r}41.6 \\
3.2 \\
8.3\end{array}$ \\
\hline
\end{tabular}

Hemorrhagic nephritis, latent onset (Type B)

\begin{tabular}{|c|c|c|c|c|c|c|c|c|c|c|c|c|c|c|c|c|}
\hline $\begin{array}{c}\text { Latent onset, ac- } \\
\text { tive stage. . . . }\end{array}$ & & & & 2 & 1 & 1 & 1 & 7 & 1 & 2 & 3 & 1 & 19 & 6 & 32.1 & $\mathbf{0}$ \\
\hline \multicolumn{17}{|c|}{ Miscellaneous group (Type C) } \\
\hline $\begin{array}{l}\text { Miscellaneous, } \\
\text { highest titers... } \\
\text { Miscellaneous, } \\
\text { lowest titers.... }\end{array}$ & $\begin{array}{l}1 \\
4\end{array}$ & 3 & 1 & $\begin{array}{l}1 \\
1\end{array}$ & 2 & $\begin{array}{l}2 \\
2\end{array}$ & $\begin{array}{l}1 \\
1\end{array}$ & $\begin{array}{l}7 \\
4\end{array}$ & 1 & & & $\begin{array}{l}3 \\
2\end{array}$ & $\begin{array}{l}18 \\
18\end{array}$ & $\begin{array}{l}3 \\
2\end{array}$ & $\begin{array}{l}16.6 \\
11.1\end{array}$ & $\begin{array}{l}0 \\
0\end{array}$ \\
\hline
\end{tabular}

from the acute stage of the disease. The streptolysin content of the serum from the remaining 19 cases was determined only after recovery. There were 40 patients who are now in a completely quiescent stage of the disease, or in whom the disease has progressed to a chronic stage or has been fatal. Four of the deaths occurred during the acute stage of the disease, 4 during the chronic stage. Nineteen of these 40 patients have been examined repeatedly from the acute stage of the disease throughout their illness. Two patients, in addition to those already cited, have been examined and are still in the acute stage of the disease.

Table VIII gives a résumé of the principal data bearing directly on the problem under investigation in all patients grouped in Type A. The infections preceding the onset of the acute nephritis in the 78 patients designated as Type $A$ were: scarlatina in 6 cases, erysipelas in 2 cases, and a severe tonsillitis, sinusitis, bronchopneumonia or infection of the skin in 59 cases. In three cases the acute nephritis, which was quite severe in one instance, developed during an acute attack of rheumatic fever with rheumatic heart disease. A severe acute infection, therefore, was known to precede immediately the onset of the symptoms of acute nephritis in 70 of the 78 cases. Excluding the instances of scarlatina, erysipelas and rheumatic fever, cultures were obtained either from the infected tissue or from the seat of the infection at different periods during the course of the nephritis in 66 of the remaining 67 cases. Either hemolytic streptococci of beta type, or the minute type, or of both types were obtained in culture from 58 of these 66 cases. It is important to note, therefore, that more or less severe acute infections due to hemolytic streptococci were known to initiate the symptoms of acute nephritis in the vast majority of the cases grouped as Type A.

There were 19 cases of hemorrhagic nephritis with latent onset, described as the second type "B." Four of these have died, the others have been examined repeatedly during the active progressive stage of the disease.

In contrast to the patients belonging to the form of acute nephritis termed Type A, the patients in Type B rarely gave a history of an acute infection, and when upon examination an infection was discovered, it was found usually to be chronic in nature. Chronic infections, often of the facial sinuses, were actually detected in 11 of 
the 19 cases. In several instances these infections were unsuspected by the patient. These chronic infections were usually associated with hemolytic streptococci, for in 15 of the 19 cases hemolytic streptococci of one or another type were cultured in significant numbers and often on several occasions from the nasopharynx, tonsils, or from the discharge from the sinuses.

In Type $\mathrm{C}$ have been placed a miscellaneous collection of cases of renal disease, including pyelonephritis, bichloride of mercury nephrosis, amyloid nephrosis, and indeterminate forms of Bright's disease seen in the chronic edematous stage. There were 18 of these cases, many of which were observed for several months.

Table VIII presents the highest antistreptolysin titers of the serum from the nephritic patients belonging to all three types. It will be seen immediately that the greatest number of high titers was obtained with the serum from patients studied during the acute phase of the disease (Type A). All patients in Type A examined during this stage of hemorrhagic nephritis, including those that died during the acute phase, those that progressed to a chronic course, and those that recovered, have been placed in this section. There were 36 patients, 26 of whom, or 72.2 per cent, gave titers above 100 units, and 15 of whom, or 41.6 per cent, gave titers above 200 units. $^{3}$ Of the total number, 17 recovered, 13 progressed either to a quiescent or chronic stage, 4 died during the acute attack, and 2 are at present still in the acute phase of hemorrhagic nephritis.

In the chronic or quiescent stage of the disease (Type A) high titers were occasionally met with in some patients, but they were much less common than during the acute stage. Only 9 of the 31 cases gave titers above 100 units, and only 1 patient gave a titer above 200 units. In the healed stage of the disease (Type A) after complete recovery, high titers were still less common, for only 6 of the 36 cases gave titers above 100 units. Five of the six cases that gave titers above 100 units were examined within one year after the onset of the nephritis.

3 Since the compilation of this data, 8 additional cases of hemorrhagic nephritis Type A, in the acute stage, have been examined. In 4 , the antistreptolysin titers of the serum were between 111 and 250 units; in 2, it was 1250 units; in 1, 1666 units; and in 1, 2,000 units.
The situation in this group of patients (Type A) is somewhat analogous to that noticed in rheumatic fever. Though the increase in antistreptolysin in the serum from patients with acute hemorrhagic nephritis is not quite so common and does not often reach quite so high a titer as it does in acute rheumatic fever, the results approximate more nearly rheumatic fever than any of the outspoken instances of infections due to hemolytic streptococci that we have studied. In addition, the same relationship holds between the two diseases in the acute and healed stages.

When the antistreptolysin response in the active stage of the disease in patients belonging to Type $B$, with latent onset, is compared with that in the acute hemorrhagic form, Type A, the difference is very striking. The determinations were frequently made at approximately the same time after onset of the disease in these two groups. In the patients with latent onset the highest titers rarely exceeded 100 units and in no case were they above 200 units.

Finally the 18 patients in the miscellaneous group of nephropathies, termed for convenience Type C, present interesting features. Repeated determinations of the antistreptolysin titers were made on many of these patients over several months, and consequently it scarcely seems possible that the unusual results are due to chance findings. Both the highest and the lowest titers are recorded. The characteristic feature is the very low titer of the serum obtained in several patients. This is frequently comparable to the low titers obtained by Lippard and Johnson (6) in infants under 18 months of age. All of these patients with very low titers were edematous. In some patients the antistreptolysin persisted at abnormally low titers for months. The serum from one patient gave titers that varied between 5.5 units and 10 units in 14 tests over a period of four months. A second patient gave titers on 9 occasions varying from 8 to 10 units over a period of 6 months, and a third patient gave titers on 7 occasions varying from 10 to 12.5 units over a period of 6 months. No explanation can be offered for these abnormally low titers of antistreptolysin.

Since it was desirable to obtain information concerning any possible relationship that might obtain between the variations in antistreptolysin 
content of the serum and the progress of hemorrhagic nephritis, the antistreptolysin curves have been charted week by week and month by month in 17 of the 36 cases who recovered (Figure 2), and in 19 of the 40 patients who are now in the quiescent stage, who have progressed to a chronic state or who have died (Figure 4). rhagic nephritis as they were in acute rheumatic fever, and that a larger proportion did not rise above the limits of normal at any time during the course of the disease.

No constant relationship could be found between the severity of the attack of acute nephritis and the height of the antistreptolysin titer, for

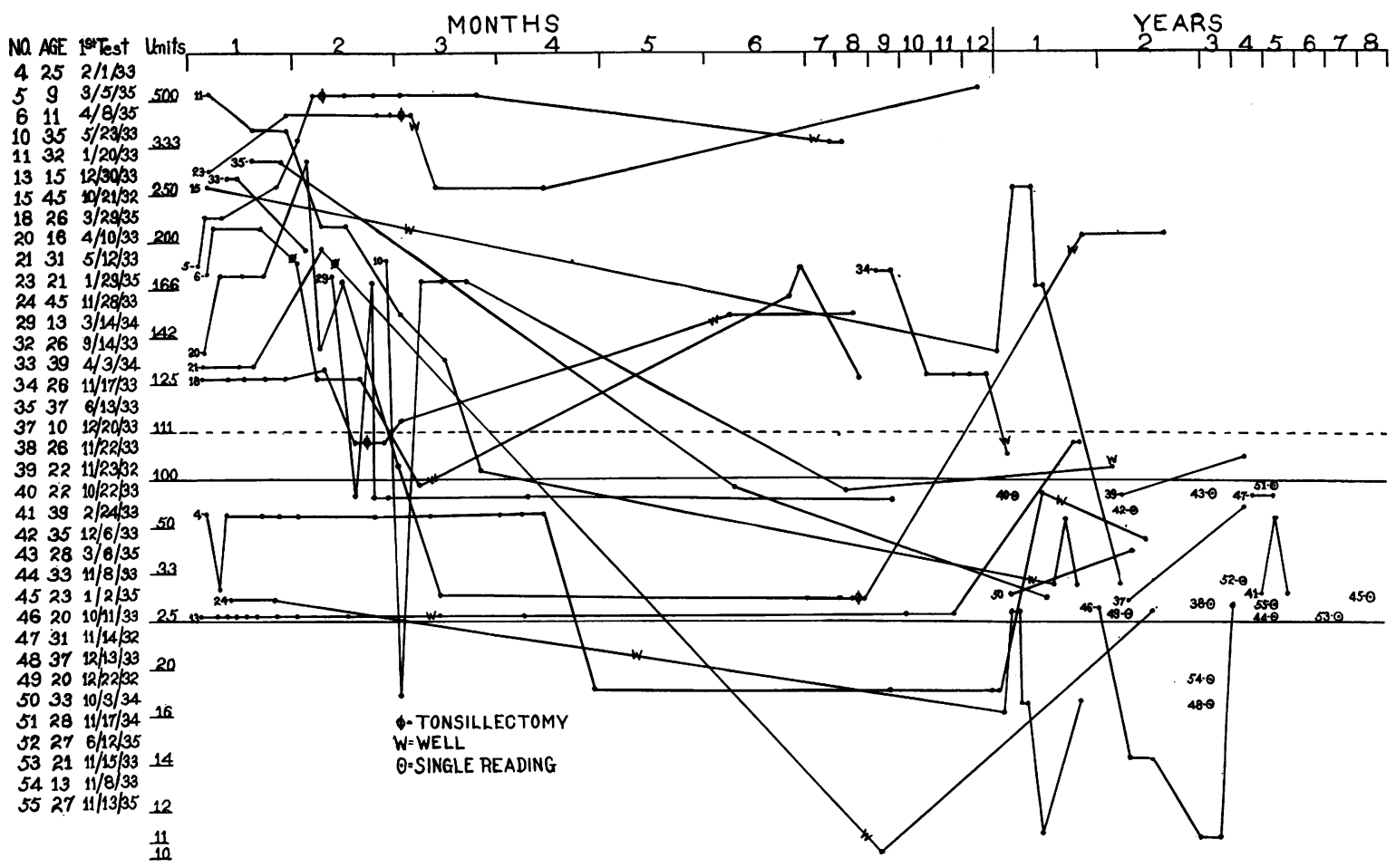

Fig. 2. Antistreptolysin Content of Serum from 36 Patients with Hemorrhagic Nephritis Type A Who Have Recovered.

The curves for the patients who have recovered have been charted in Figure 2. In general the trend of the curves simulated that obtained in acute rheumatic fever, inasmuch as the antistreptolysin titers in the majority of the patients were high in the first weeks or even months of the disease. As convalescence was established and as recovery took place, the curves tended in several cases to decline to the normal levels. One to five years after complete recovery was established, the titers from all but two of 29 cases were within normal limits, and in 24 cases lay between 16.7 and 50 units. Though the general appearance of the curves resembles that in acute rheumatic fever, it was found, as the chart shows, that the original titers were not so high in acute hemor- some patients, suffering from much the same form of infection preceding the attack of nephritis, showed totally dissimilar curves, with high titers in one and persistently low titers in another (Figure 2, Number 4, and Figure 4, Number 19). The rapidity with which the titers fell to low levels did not seem to be regularly allied to the form of infection caused by hemolytic streptococci, to the severity of the nephritis, or to the rapidity with which the patients recovered from the nephritis (Figure 3). After comparatively mild infections, followed by attacks of nephritis of only moderate severity with rapid recovery, the antistreptolysin titer remained high in some patients for months, whereas in others, having severe infections followed by alarmingly severe attacks of 
nephritis, the titers fell rapidly with recovery (Figure 2, Number 5; Figure 3, Number 11). Whenever the titer was high during the acute phase of nephritis, it remained elevated in most cases beyond the time at which all evidences of nephritis had entirely disappeared (Figure 2, Number 5).

Another interesting irregularity was the sudden secondary rises in titers after the patient had recovered and after the antistreptolysin content of the serum had dropped to a normal figure. This streptococci in the pharynx of these patients might account for such irregularities. Examination of the bacteriological flora of the throat from the patients who have recovered have been made in many instances by Dr. Long, within a few months or weeks of the time that the titers of the serum were determined. Seventeen of the cases have given at least one positive culture; 16 of the cases did not at any time show hemolytic streptococci, and in three cases cultures were not obtained. Since 12 of the cases with low titers

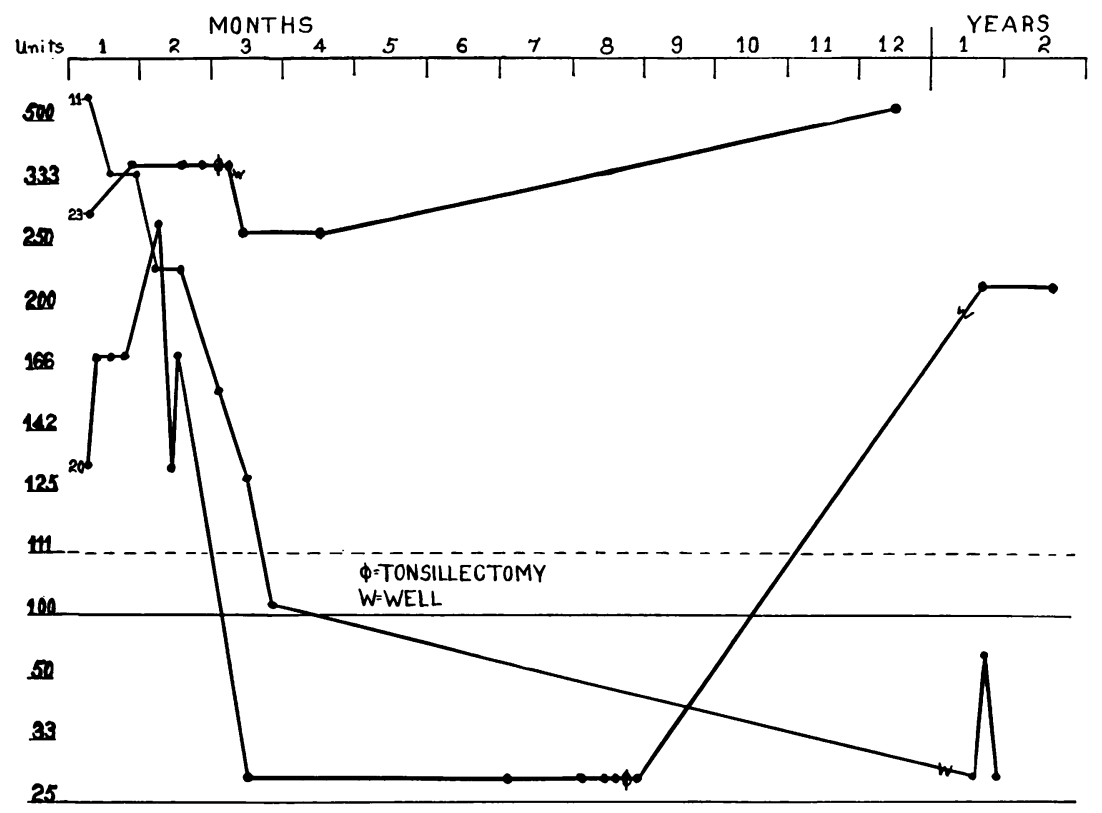

\section{0}

Fig. 3. Antistreptolysin Content of Serum from 3 Cases of Acute Hemorrhagic Nephritis Type A That Hate Recovered.

occurred in seven patients. In one (Figure 2, Number 6) the secondary rise could be explained by the fact that the patient contracted an attack of impetigo due to hemolytic streptococci. This infection was not accompanied or followed by signs of exacerbation of hemorrhagic nephritis. One of the other four patients had rheumatic fever, but the rise of titer in the remaining 5 cases was not connected, as far as could be discovered, with any infection due to hemolytic streptococci (Figure 3, Number 20). In one patient (Figure 2, Number 15 ) the secondary rise was of comparatively short duration. It is, however, possible that the mere presence of hemolytic gave, on at least one occasion, a positive culture for B. hemolytic streptococci, it hardly seems possible that the temporary carrier state could account for high antistreptolysin titers. All of the patients with high titers after recovery showed hemolytic streptococci in the throat culture on one or more occasions, but in three of the five cases in which an adequate explanation was not found, the examinations and titers were made within 4 to 7 months of the acute attack of nephritis. In one instance, Figure 3, Number 20, the high titer was obtained 2 years after the attack.

The antistreptolysin curves for 19 patients in whom the acute hemorrhagic nephritis (Type A) 
progressed to a quiescent stage, became chronic or caused death, are charted in Figure 4. They present a somewhat different appearance from those in Figure 2, for the curves usually remain persistently higher or are broken by sudden eleva- patients the titer was high during the first few weeks of the disease (during first month in 21 and during first two months in 31 of 35 cases), though in a few the titer never rose above the normal figure. There was a tendency for the

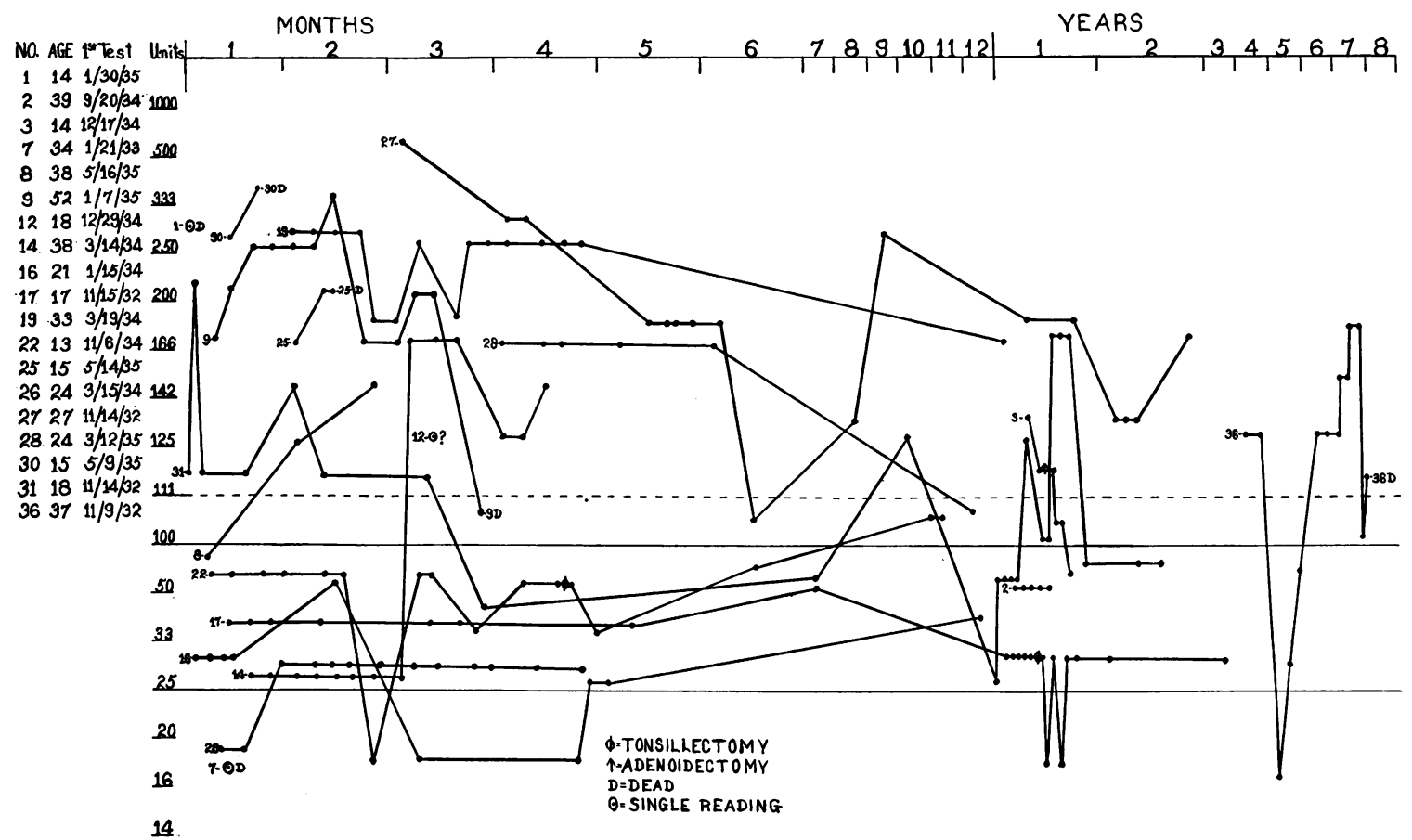

Fig. 4. Antistreptolysin Content of Serum from 19 Patients with Hemorrhagic Nephritis Type A Who Have Progressed to Latent or Chronic Stage or Who Have Died.

tions which are coincident with remitting acute infections accompanied by exacerbations of the nephritis. This is especially noticeable in Cases 19, 27 and 31 (Figure 5). It is also to be observed that high titers persist in some cases for many months or years (Figure 5, Number 27) and were found in one case (Figure 4, Number 36) from 4 to 7 yaars after the primary attack of nephritis. In a few cases, notably Numbers 17 and 26 (Figure 4), the titers never rose above normal. One of these patients has been followed for 3 years.

From a study of the curves of the antistreptolysin titers in these 36 patients, 17 of whom recovered (Figure 2), 19 of whom are now in quiescent stage, have progressed to a chronic stage or are dead (Figure 4), it may be said that no very constant relationship was found to exist between the form of the disease and the curve of the antistreptolysin titer. In the majority of all antistreptolysin titer to fall as the patient recovered, but high titers were obtained weeks or months after complete recovery had been established, and occasionally there was a secondary rise, months or even a year or two following complete recovery and after the titer had previously reached normal.

While the disease was still quiescent or when it progressed to a chronic stage, the antistreptolysin titer remained at a high level in a fair proportion of instances, and in some persisted at these levels for years.

It is important to bear in mind that in the vast majority of these patients comparatively severe infections by hemolytic streptococci preceded the onset of the nephritis by an interval of a few days to a few weeks, and that in many of the chronic cases evidence of infection persisted throughout the course of the disease.

The 19 patients of Type B with latent onset 


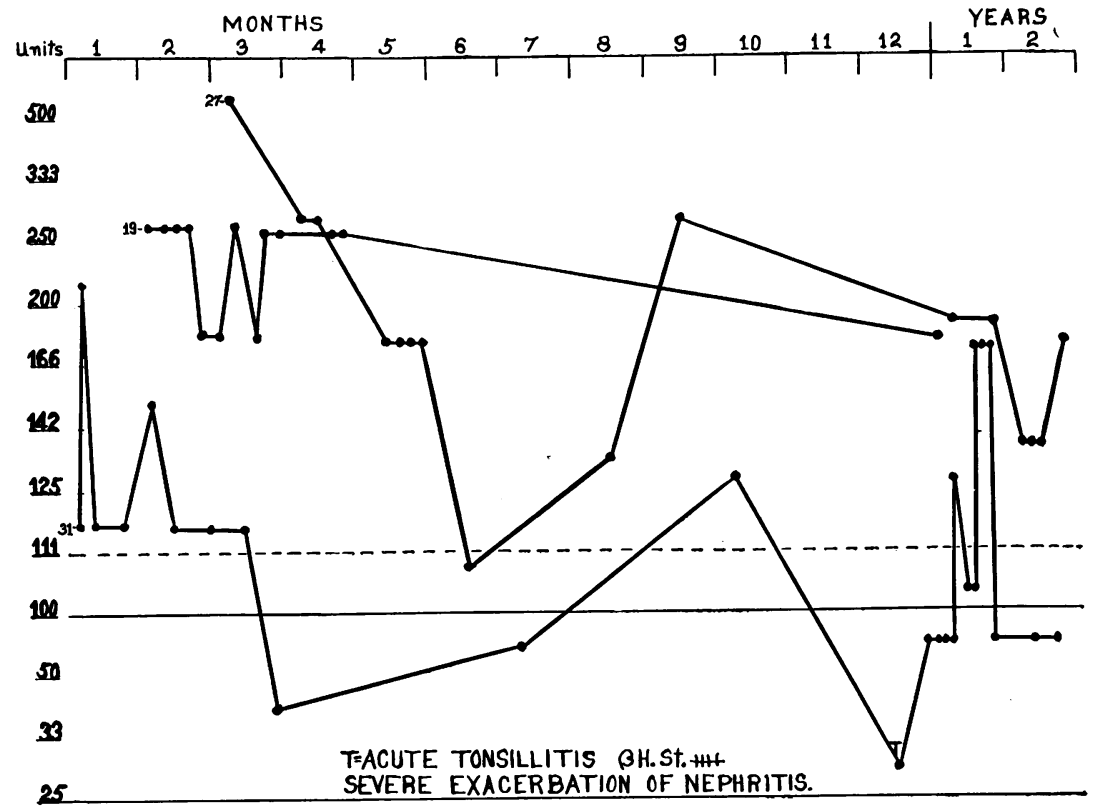

Fig. 5. Antistreptolysin Content of Serum from 3 Cases of Acute Hemorrhagic Nephritis Type A in Quiescent or Chronic Stage.

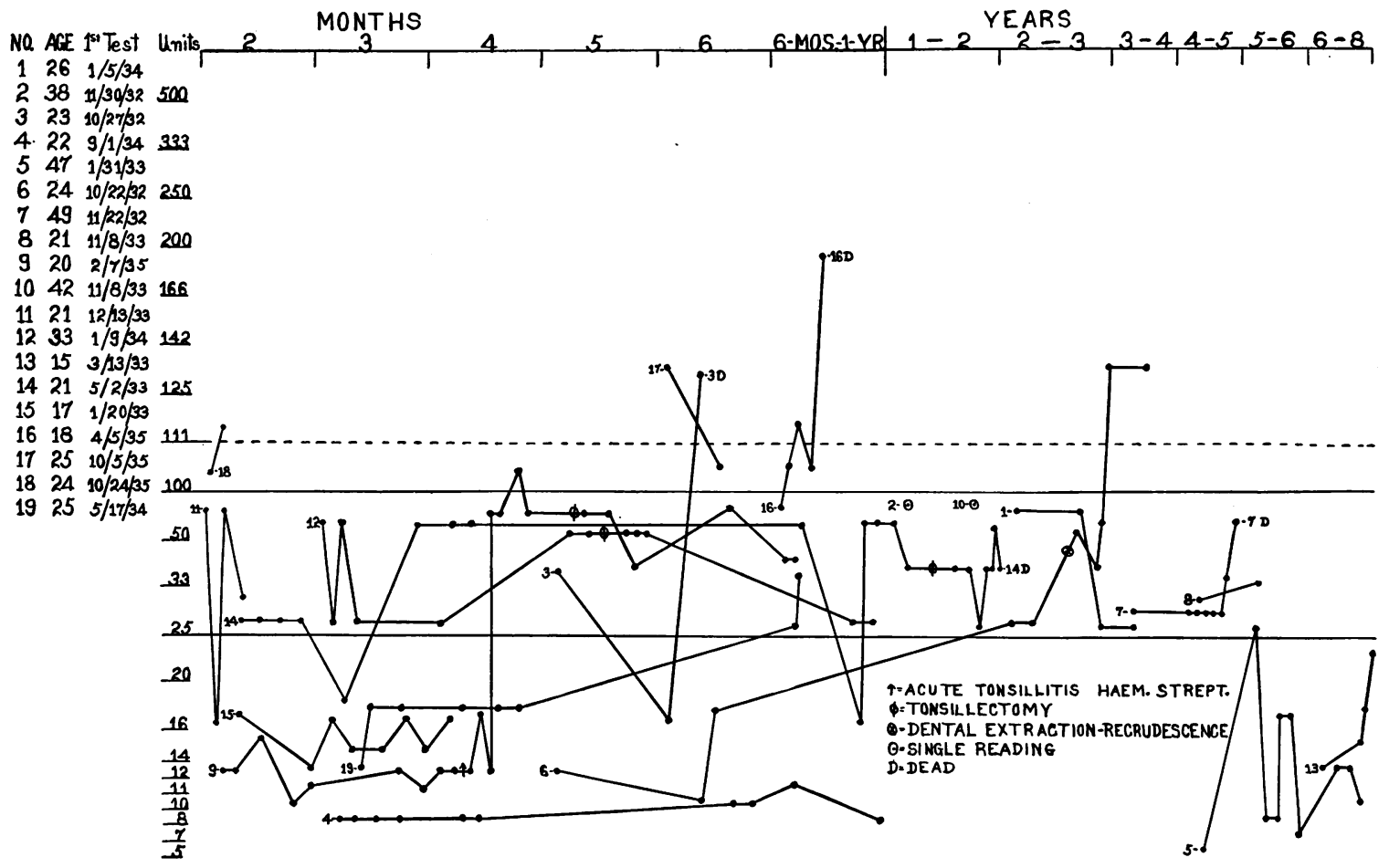

Fig. 6. Antistreptolysin Content of Serum from 19 Cases of Hemorrhagic Nephritis Type B. 
present an interesting problem. Antistreptolysin titers were determined in at least 8 of them during the first three months of the disease, or as near this time as could be determined from the histories (Figure 6). The characteristic of these cases (Type B) was the persistently low level of the antistreptolysin titer. In only 5 out of the 19 cases did the titer rise at any time above the normal level, and in 2 this occurred just before death. It will also be noted that these low levels persisted for months and years. Two cases are of particular interest, Numbers 9 and 6 (Figure 6). $\mathrm{Pa}$ tient Number 9 experienced, during the fourth month of her disease, a severe acute attack of tonsillitis due to $\mathrm{B}$. hemolytic streptococci. This was accompanied by gross hematuria. Immediately after this acute attack, the antistreptolysin titer rose from 12.5 units to 16.7 units, and during the next two weeks rose abruptly to 100 units. During the following two months the titer varied from 50 units to 33.3 units, but at no time, even after the acute infection, did the titer rise above normal. Patient Number 6 had shown variations in titer between 10 and 25 units for about 2 years when suddenly after an infection about a tooth, which later was extracted, the titer rose from 50 to 125 units, where it has remained for 8 months.

Another interesting feature is the very low titer which at times these patients may show. Titers between 7 and 10 units were obtained on one or several occasions with the blood serum from 4 of these patients $(4,5,6,9)$.

The explanation for the persistently low titers in the patients of this type is not clear. Practically all of them have had or now have more or less marked edema though, in several, during the latter stages of the disease this has been confined to slight pitting over the shins. In all, the plasma proteins have been reduced below the normal level. Though many of them have infections, often caused by hemolytic streptococci, the local reaction to the infection is sluggish, and, as has been pointed out by Winkenwerder, McLeod and Baker (5), the onset of the disease, being insidious, is quite different from that observed in the patients grouped in Type A. It is possible that the reactive processes of the body are partially suppressed in this group. This might result in an ineffective reaction against the infection as well as against the lesions in the kidney; and the low titers of antistreptolysin may be actually another indication of the lack of response of the protective mechanism. Another explanation might be found in the possibility that the infection and the accompanying nephritis is primarily associated with an organism other than the hemolytic streptococcus. Rake and Blackman (7) have recently recalled attention to the fact that acute hemorrhagic nephritis may occur as a result of infections by pneumococci, and Seegal (8) supports this view. Blackman (9) has been able to produce experimentally in rabbits through the repeated intravenous injection of pneumococcus toxin a form of nephritis accompanied by edema.

It might be argued, therefore, that the hemolytic streptococci occur in these patients accidentally, or as an inactive associated organism, and thus cannot be regarded as the immediate cause of the infection. The fact remains, however, that in at least one patient a severe tonsillitis due to hemolytic streptococci was not followed by a rise in titer above normal.

Discussion of the conditions in the third group is not necessary, since there was no indication that the various forms of disease of the kidney were in any way connected with infections due to hemolytic streptococci.

\section{DISCUSSION}

The observations that we have made accord with those of others, and add further evidence to show that infections by hemolytic streptococci are sometimes accompanied, but are more often followed, by a significant rise in the antistreptolysin content of the blood serum. The rise does not usually occur until one to three weeks after the onset of the infection. It reaches its highest titer promptly, and, then, after a variable length of time, falls sometimes rapidly but frequently slowly to the normal level. The period during which the antistreptolysin titer persists at an abnormally high level is extremely variable. The titer does not always fall immediately with recovery from the disease, for high titers may be encountered for weeks or months after the patient is entirely well. This may occur following mild as well as severe infections. On this account, if 
for no other reason, the test cannot be employed for diagnostic purposes, unless the actual change from a normal titer to a high titer occurs under observation.

The height to which the antistreptolysin titer rises does not seem regularly to be dependent upon the severity of the infection. Indeed as was first noted by Todd (1), fatal infections by hemolytic streptococci may not be accompanied by any increase in the antistreptolysin content of the blood. Coburn and Pauli (2) have, however, presented evidence to show that the height of the antistreptolysin titer parallels to a certain extent the severity and duration of acute attacks of rheumatic fever, but this has not been the usual experience with streptococcal infections in general, nor has it occurred in our small series of cases.

There appears, also, to be some variation in the production of abnormal amounts of antistreptolysin in different forms of streptococcal infection. In our series, increase in antistreptolysin frequently did not occur after acute tonsillitis and pharyngitis, and in the patients in which the antistreptolysin did increase it rarely reached a high titer. Coburn and Pauli (2) have called attention to this same occurrence in their series. An increased antistreptolysin was more common in scarlatina and high titers more frequent, while antistreptolysin was regularly increased in erysipelas, and high titers were the rule. Under these circumstances it appears somewhat peculiar that in rheumatic fever and hemorrhagic nephritis, both of which are so commonly preceded by acute streptococcal tonsillitis and pharyngitis, the antistreptolysin should be so regularly elevated to a high titer during the acute stage of the disease.

One might advance this as an argument to uphold the view that both diseases are caused by hemolytic streptococci, but it is obvious, from the previous experiences, that persistently high titers of antistreptolysin may be obtained for weeks following all varieties of streptococcal infection. This raises a valid objection to using this test as an indication that any complication of a streptococcal infection is in itself due to hemolytic streptococci. The observations can undoubtedly be interpreted, however, as meaning that both diseases are preceded with remarkable constancy by infections due to hemolytic streptococci, but scarcely warrant any further conclusion in regard to the etiology of acute hemorrhagic nephritis or acute rheumatic fever.

It seems probable that other explanations may be offered to account for the regularity of the relatively high antistreptolysin in these conditions.

In the first place, it is possible that certain strains of hemolytic streptococci may call forth the production of greater amounts of antistreptolysin than others. There is, however, no direct evidence that would uphold this view.

In the second place, it is conceivable that the reactive processes of different individuals may not respond either qualitatively or quantitatively in the same way to a similar stimulus. Under such circumstances there might be a wide variation in the frequency with which increased amounts of antistreptolysin appeared in the serum and in the height to which it rose in different forms of streptococcal infections. The differences, under these circumstances, would depend less upon the form of infection than upon the peculiar reaction of the individual to this infection. Such an interpretation would accord very well with the observations made upon the two forms of nephritis designated as $A$ and $B$. In the first type, high titers were the rule; in the second type, high titers were practically absent, and even when in the Type B cases the titrations were made during and following an exacerbation of nephritis coincident with a severe tonsillitis due to B. hemolytic streptococci, an increase in the titer above normal was not observed.

If further studies show that the observations already recorded occur with considerable constancy, they would still further support the view that the formation of antistreptolysin reflects the degree to which the reactive processes of the body respond in certain forms of streptococcal infections or in some diseases following streptococcal infections. It might be found that the response of this particular antibody is exaggerated in erysipelas, ${ }^{4}$ scarlatina, rheumatic fever and in one form of acute hemorrhagic nephritis. It is to be remarked that in all of these diseases an allergic

\footnotetext{
4 Spink and Keefer have recently published data to show that the antistreptolysin content of the serum from patients with erysipelas, increased regularly and often rose to a very high titer within the first 20 days after the onset of the illness. High titers persisted for periods of 40 days to 6 months.
} 
factor is considered by many to play a more or less definite part in the pathogenesis and natural history of the process. There is no particular reason, however, to suppose that the allergic factor and the antistreptolysin response are in any way related.

\section{CONCLUSIONS}

1. Repeated determinations of the antistreptolysin content of the serum from normal individuals and from patients suffering from a variety of chronic diseases unrelated to streptococcal infections showed that the titer in the majority of cases fell between 25 and 50 units and rarely exceeded 100 units.

2. In acute infections, due to agents other than hemolytic streptococci, titers above 100 units were encountered a little more frequently (22.7 per cent of 66 cases).

3. Significant increases in antistreptolysin were found in the serum from patients with streptococcal infections. This occurred in order of frequency and in height of elevation in acute tonsillitis and pharyngitis, in miscellaneous infections, in scarlet fever, erysipelas and rheumatic fever. In acute rheumatic fever the antistreptolysin titers were regularly and markedly increased.

4. High antistreptolysin titers were also obtained regularly in one form of acute hemorrhagic nephritis designated as Type A. In a second form, also preceded by streptococcic infections, designated Type $B$, but with insidious onset, the antistreptolysin titers were rarely above the normal and were in some patients unusually low.

5. Though some correlation could be noted between the antistreptolysin curves and the course of the disease in patients with acute rheumatic fever and with acute hemorrhagic nephritis, this was not very close.

6. Reasons are given for concluding that the occurrence almost constantly of the high antistreptolysin titers that are observed during the course of acute rheumatic fever and acute hemorrhagic nephritis, only indicate the recent occurrence of an infection due to hemolytic streptococci and cannot be used as evidence that these diseases are caused by hemolytic streptococci.

7. There appears to be a difference of reactivity amongst individuals suffering from different forms of streptococcal infections. This leads to variation in the production of antistreptolysin.

8. Patients suffering from acute rheumatic fever and from acute hemorrhagic nephritis (Type A) appear to be especially prone to the formation of antistreptolysin in comparatively large quantities.

I am indebted to Miss Anne Austin McLanahan for assistance in compiling the tables.

\section{PROTOCOLS}

Number 11. Antistreptolysin first determined January 20 , fourteenth day of disease. Male, colored, age 32 . Admitted J. H. H. January 18, 1933, with pain in chest and swelling of eyes. Always well until December 26, 1932, when he developed erysipelas, complicating epidemic parotitis. During acute attack urine normal. On January 6 , trace of albumin in urine; on January 12 , swelling of ankles, pain in side, shortness of breath. On admission, anasarca, râles at bases of lungs, slight enlargement of heart, blood pressure 170/100, exudates and hemorrhages in retinae, leukocytes 5,850, albuminuria, cylindruria and marked hematuria; phthalein 65 per cent; N.P.N. 28. Urea clearance 40 per cent normal maximum. Albumin and red blood cells in urine diminished rapidly. Discharged April 5. No edema, blood pressure 120/90, phthalein 80 per cent, N.P.N. 30, urea clearance 91 per cent normal maximum, urine concentrated specimen (Addis count) albumin trace, red blood cells diminished from 21 million to 2.5 million. April 19, 1934, readmitted to hospital with generalized infection by Bacillus suipestifer. Recovered after febrile illness of 18 days. During illness urine showed no albumin, no red blood cells, no casts. May 10, 1934, Addis count-specific gravity 1,027 , protein 40 , red blood cells 300,000 , leukocytes $1,000,000$, no casts, phthalein 78 per cent, urea clearance 130 per cent normal standard. Blood pressure $110 / 82$ to $95 / 65$.

Number 20. Antistreptolysin first determined April 10, fifth day of disease. Male, white, age 16. Admitted to J. H. H. April 8, 1933, with swelling of face and ankles for 3 days. In November, 1932, appendectomy; blood pressure 90/70. Urine normal. On March 16, 1933, scarlatina. On April 5, 1933, 20 days later, swelling of face, ankles, headache, vomiting, frequency of urination and some fever. On admission, third day of illness, temperature $101.6^{\circ}$, anasarca, pleural eff usion, hemorrhage in retina, swollen tonsils, presystolic gallop rhythm. Blood pressure $180 / 115$, leukocytes 9,100 . Urine smoky, albumin 0.6 per cent, many red blood cells, leukocytes and casts. Cultures from pharynx-B. hemolytic streptococcus +++ , phthalein 80 per cent, N.P.N. 30. Rapid improvement. April 13, blood pressure 136/80, loss of edema with diuresis. Discharged May 28, 1933, symptomatically well. Blood pressure $110 / 64$, phthalein 70 per cent, N.P.N. 33, urea clearance 65 per cent normal standard. Concentrated specimen of urine (Addis count) 
normal. December 4, 1933, tonsillectomy. Blood pressure $115 / 70$, phthalein 70 per cent, urea clearance 120 per cent normal standard. Urine concentration 1,016 to 1,030. December 15, 1933, Addis count-specific gravity 1,030 , protein 34 , red blood cells $1,700,000$, casts 3,000 . January 25, 1934, blood pressure 110/70. Urine-no albumin, red blood cells, or casts. Well. December 19, 1934, blood pressure 120/74. Urine-no albumin, no casts, no red blood cells. October 9, 1935-urine, no albumin, no casts, no red blood cells.

Number 23. Antistreptolysin first determined January 29, tenth day of disease. Female, colored, age 21. Admitted to J. H. H. January 28, 1935. Past health excellent. On January 5, 1935, severe cold and sore throat, followed by cough and swelling of legs and abdomen on January 19, 1935. A few days later nausea, vomiting, headache, nocturia and generalized edema. On examination, pallor, anasarca, exudate over enlarged tonsils, bilateral hydrothorax, enlargement of cardiac dullness, systolic murmur. Blood pressure $158 / 110$, edema of retina, enlargement of liver and spleen and ascites. Urine clear, specific gravity 1,012 , acid, albumin + , hyaline and granular casts ++ , red blood cells +++ , leukocytes +++ . Cultures from tonsils $B$. hemolytic streptococcus +++ . Phthalein 40 per cent, N.P.N. 30, urea clearance 42 per cent normal standard. Rapid improvement with loss of edema, fall of blood pressure and diminished albuminuria within 10 days. March 9, tonsillectomy without reaction. Discharged March 23, without edema, traces of albumin and a few red blood cells in urine. Blood pressure $90 / 60$, phthalein 90 per cent, urea clearance 78 per cent normal standard. April 3, 1935, the physical examination and urine showed nothing abnormal. Blood pressure 104/66. Urine concentrated specimen-acid, albumin trace, no casts, no red blood cells. November 27, 1935, perfectly well. Blood pressure 104/70. Urine showed no albumin, no casts, no red blood cells.

Number 19. Antistreptolysin first determined March 19, second month of disease. Male, white, age 33. Admitted to J. H. H. March 18, 1934, with fistula in ano, localized dermatitis, albuminuria and hematuria. Excessive alcohol. For 2 years, frequent "boils"; for 9 months local infection on left arm. Five months ago, swelling of face; 2 months later blood pressure found to be high and urine to contain albumin and blood. On admission, pasty, face slightly puffy, heart slightly enlarged. Blood pressure $142 / 90$, perianal scars, elevated red granulating lesion $3 \times 5 \mathrm{~cm}$. on left arm, cultures from which show numerous B. hemolytic streptococcus in pure culture. Hemoglobin 72 per cent, red blood cells $3,800,000$; leukocytes 8,100 . Urine: specific gravity 1,010 , albumin + , red blood cells ++++ , casts ++ . Phthalein 48 per cent, N.P.N. 34; urea clearance 62 per cent normal standard. Removal of infection on arm. Discharged June 23, 1934, condition unchanged. Blood pressure 138/95. General health after discharge good, but albuminuria and hematuria persisted. April 24, 1935, no edema, color good. Operative wound healed. Blood pressure 155/105. Phthalein 70 per cent; urea clearance
73 per cent normal standard. Urine: specific gravity 1,025 to 1,037 , albumin ++ , many red blood cells and casts.

Number 27. Antistreptolysin first determined November 14, 1932, third month of disease. Male, white, age 27. Admitted to J. H. H. November 9, 1932, with swelling of face and ankles, vomiting and bloody urine. Rheumatic fever at 15; chronic discharging ear for 20 years. In August, 1932, severe sore throat with fever; two weeks later vomiting and abdominal pain, followed after a week by swelling of face and feet, with bloody urine. Since onset swelling has decreased but bloody urine continues. On admission, no edema, discharging right ear, presystolic gallop rhythm. Blood pressure 138/84. Right kidney palpable. Leukocytes 6,600. Urine: smoky, albumin 0.6 per cent, grossly bloody, many leukocytes and casts. Phthalein 55 per cent. Culture of sputum B. hemolytic streptococcus. Discharged in practically the same condition. December 22, 1932-remains symptomatically well, but persistent albuminuria and hematuria. December 5, 1934 blood pressure 128/88, N.P.N. 36; urea clearance 105 per cent normal standard, total blood protein 6.5 grams per liter. Phthalein 75 per cent. Urine: specific gravity 1,007 to 1,023 . Urine concentrated (Addis count) protein 147 mgm., red blood cells $6,000,000$, casts 700,000 . May 1, 1935, symptomatically well. Blood pressure $128 / 74$. Urine: albumin + , hyaline and granular casts + , red blood cells +++ .

Number 31. Antistreptolysin first determined November 14, fourth day of disease. Female, white, age 18. Admitted to J. H. H. November 13, 1932, with backache, fever and bloody urine. Always healthy, no previous infections. Seven days before admission, pain in back; 3 days later, chills, vomiting; next day, headache, anuria and then bloody urine, cough, fever. On admission, temperature $102.4^{\circ} \mathrm{F}$., looks ill, face puffy, swollen tonsils. Solidification left lower lobe, bilateral costovertebral tenderness. Blood pressure 110/70. Edema over tibia. Leukocytes 5,000. Urine: albumin +++ , red blood cells ++++ , leukocytes and casts +++ . N.P.N. 120. Culture from throat: many B. hemolytic streptococcus. Sputum: many B. hemolytic streptococcus, and pneumococcus Group IV. After first week, improvement in general condition, but appearance of generalized rash lasting 3 days, rise in blood pressure to $140 / 100$; phthalein 30 per cent. By December 5th, gradual decrease in N.P.N. to 36 , and of blood pressure to $125 / 90$. Later slow improvement and on discharge February 15, 1933, urine showed only trace of albumin, occasional red blood cells and few casts. Phthalein 80 per cent. In good physical condition, but albuminuria, hematuria and cylindruria persist up to January 1, 1934, when, after severe attack of tonsillitis due to $\mathrm{B}$. hemolytic streptococcus, edema appeared, albumin, red blood cells and casts increased in urine. N.P.N. rose to 108 on January 5, and phthalein fell to 4 per cent; blood pressure 108/68. Gradual improvement. Tonsillectomy February 15, followed by increased albuminuria, hematuria and cylindruria. January 8, 1936, symptomatically well. Blood pressure 
110/70. Urine: pale, albumin questionable, occasional red blood cells and leukocytes, no casts.

\section{BIBLIOGRAPHY}

1. Todd, E. W., Antihaemolysin titres in haemolytic streptococcal infections and their significance in rheumatic fever. Brit. J. Exper. Path., 1932, 13, 248.

2. Coburn, A. F., and Pauli, Ruth H., Studies on the immune response of the rheumatic subject and its relationship to activity of the rheumatic process. VI. The significance of the rise of antistreptolysin level in the development of rheumatic activity. J. Clin. Invest., 1935, 14, 769.

3. Todd, E. W., A comparative serological study of streptolysins derived from human and from animal infections, with notes on pneumococcal haemolysin, tetanolysin, and staphylococcus toxin. J. Path. and Bact., 1934, 39, 299.

3a. Lancefield, Rebecca C., A serological differentiation of human and other groups of hemolytic streptococci. J. Exper. Med., 1933, 57, 571.

4. Lancefield, Rebecca C., and Hare, Ronald, The serological differentiation of pathogenic and non-pathogenic strains of hemolytic streptococci from parturient women. J. Exper. Med., 1935, 61, 335.

5. Winkenwerder, W. L., McLeod, N., and Baker, M., Infection and hemorrhagic nephritis. Arch. Int. Med., 1935, 56, 297.

5a. Long, P. H., and Bliss, E. A., Studies on minute hemolytic streptococci. I. The isolation and cultural characteristics of minute beta hemolytic streptococci. J. Exper. Med., 1934, 60, 619.
Long, P. H., Bliss, E. A., and Walcott, C. F., II. The distribution of minute hemolytic streptococci in normal and diseased human beings. J. Exper. Med., 1934, 60, 633.

6. Lippard, V. W., and Johnson, P., Beta hemolytic streptococcic infection in infancy and in childhood. I. Antifibrinolysin and antistreptolysin response. Am. J. Dis. Child., 1935, 49, 1411.

7. Rake, G., Nephritis in pneumococcal infections. Guy's Hosp. Rep., 1933, 83, 430.

Blackman, S. S., Brown, J. H., and Rake, G., The production of acute nephritis by means of a pneumococcal autolysate. Bull. Johns Hopkins Hosp., 1931, 48, 74.

Blackman, S. S., and Rake, G., Acute pneumococcal nephritis. Bull. Johns Hopkins Hosp., 1932, 51, 217.

8. Seegal, D., Acute glomerulonephritis following pneumococcic lobar pneumonia. Arch. Int. Med., 1935, 56, 912.

9. Blackman, S. S., Jr., Pneumococcal lipoid nephrosis and the relation between nephrosis and nephritis. I. Clinical and anatomical studies. Bull. Johns Hopkins Hosp., 1934, 55, 1.

Blackman, S. S., Jr., On the pathogenesis of lipoid nephrosis and progressive glomerulonephritis. Bull. Johns Hopkins Hosp., 1935, 57, 70.

10. Coburn, A. F., and Pauli, R. H., Limited observations on the antistreptolysin titer in relation to latitude. J. Immunol., 1935, 29, 515.

11. Spink, W. W., and Keefer, C. S., Studies of hemolytic streptococcal infection. II. The serological reactions of the blood during erysipelas. J. Clin. Invest., 1936, 15, 21. 